九州大学学術情報リポジトリ

Kyushu University Institutional Repository

Systematic and biological studies of the family Andrenidae of Japan (Hymenoptera, Apoidea) Part 2. Systematics, 3

Hirashima, Yoshihiro

Entomological Laboratory, Department of Agriculture, Kyushu University

https://doi.org/10.5109/22712

出版情報: 九州大学大学院農学研究院紀要. 13 (1)，pp.39-69，1964-03. Kyushu University バージョン：

権利関係 : 
Journal of the Faculty of Agriculture, Kyushu University, Vol. 13, No. 1

March 30, 1964

\title{
Systematic and biological studies of the family Andrenidae of Japan (Hymenoptera, Apoidea) \\ Part 2. Systematics, $3^{*}$
}

\author{
Yoshihiro HIRASHIMA
}

\section{Subgenus Cnemidandrena Hedicke}

Cnemidandrena Hedicke, 1933, Mitt. Zool. Mus. Berlin, 19: 212; Lanham, 1949, Univ. Calif. Pub. Ent., 8: 211; Hirashima, 1952, Mushi, 24: 61.

Type-species: Melittanigriceps Kirby, 1802. (Original designation.)

Diagnosis: The female of this subgenus can easily be recognizable by having the abundant hairs on the body (although hairs on the metasoma not specially long and dense), the well developed propodeal corbicula, the conspicuous hair band on each metasomal tergum (although band of 1st tergum usually obscure or sometimes lacking), the expanded mid basitarsi which is about as broad as or broader than the hind basitarsi, and the more or less compact tibial scopa which is, however, composed of rather short to short hairs on the outer faces.

The male is readily recognized by the process of labrum which is strongly protuberant and excavated beneath.

Cnemidandrena is found both in the Old and New Worlds. Speceis of this subgenus fly in late summer or autumn. In our region, only two species have been found.

Description: Small to medium-sized species, integument black. Head of moderate size in female, rather large in male; inner eye margins subparallel, occasionally slightly convergent above in male ; process of labrum reflected at apex, slightly to deeply emarginate in female, protuberant and excavated beneath in male ; thorax with or without black pubescence; propodeal enclosure poorly to more or less well indicated, finely sculptured or weakly wrinkled basally; dorsal face of propodeum as well as mesopleuron usually finely sculptured, not roughened ; fore wings with three submarginal cells; metasoma with posterior depressions of terga indistinct.

Female: Facial fovea wide, separated from eye margin by a narrow to wide space, variable in length; 3rd antennal segment subequal to 4th plus 5th ; propodeal corbicula well developed; with dorsal fringe of long, dense, well arranged hairs; interior of corbicula with coarse hairs anteriorly, free of hairs posteriorly ;

* Contribution Ser. 2, No. 184, Entomological Laboratory, Kyushu University. 
trochanteral floccus imperfect to nearly perfect; femoral floccus dense, with or without sparse branched hairs anteriorly; tibial scopa compact, composed of rather short to short, simple hairs; mid basitarsi strongly widened medially, usually broader than hind basitarsi; hind tibiae rather short, dilated specially; tibial spurs normal; posterior margins of metasomal terga with conspicuous hairs, although band of 1 st tergum obscure or sometimes lacking.

Ma le: Clypeus black; nearly flat in our species; 3rd antennal segment longer than 4th; cheeks broader than eyes, with posterior margins occasionally carinate; mandibles rather long and slender, well decussate; p'osterior margins of intermediate metasomal sterna with or without dense fringe of curled hairs; genitalia with parapenial lobe slightly produced; paramere elongate, slightly expanded apically; aedeagus slender or slightly expanded basally, not excavated laterally.

\section{(21) Andrena (Cnemidandrena) seneciorum sp. nov.}

This species is primarily characterized by the presence of the brown to fuscous hairs on the mesoscutum, and is easily separated from this point from Andrena fuscipes (Kirby) and its allied species. So far as the blackened hairs on the thorax are concerned, seneciorum is referred to denticulata (Kirby), but is readily separated from it by the absence of the abundant black hairs on the head and thorax, the more sparsely and more strongly punctate clypeus, the more broad and less compact tergal hair bands, etc.

This species is known from Hokkaido and the mountaneous region of central Honshu. It flys in August, and probably passes a generation in a year. It is not rare in Hokkaido, and primarily associates with the flowers of Senceio.

Female: Length $10-11 \mathrm{~mm}$.

Colour: Black; mandibles broadly reddened apically and occasionally basal halves of mandibles piceous; bases of mandibles and malar spaces reddened or piceous; flagellum beneath excepting basal one or two segments reddish brown or yellowish brown; wings subhyaline with distal margins slightly darkened; veins and stigma brown ; tegulae brown, not transparent; legs piceous; mid basitarsi and hind tibiae and basitarsi distinctly reddish brown; small segments of tarsi, especially hind ones, yellowish; tibial spurs yellowish ; posterior margins of metasomal terga narrowly nearly discoloured.

Pubescence: Hairs on head rather abundant; hairs on clypeus, supraclypeal and antennal regions and cheeks moderately long, rather dense to dense, dull white to slightly yellowish, those on vertex fuscous, those on occiput pale, occasionally brownish; facial fovea chocolate to blackish; hairs on thorax abundant and long except for those on median portion of mesoscutum which are shorter and sparser than those on mesopleuron, and not obscure integument; hairs on thorax dull yellowish gray above and whitish below except for rather sparse to rather dense fuscous hairs on mesoscutum and scutellum; propodeal corbicula quite well developed with dorsal fringe of long, dense, well arranged, distinctly yellowish hairs ; interior of corbicula with sparse, long, coarse hairs anteriorly; hairs on trochanters and femora, including trochanteral and femoral floccus of hind legs, pale to yellowish ; apical tufts of hind femora fuscous; hairs on outer faces of tibiae and basitarsi of all legs reddish brown to fuscous; tibial scopa usually slightly yellowish beneath and occasionally distinctly fuscous above ; trochanteral floccus imperfect, rather dense; femoral floccus dense, with sparse 
branched hairs on dorsal margins of femora; tibial scopa compact, composed of rather short to short, more or less well arranged, simple hairs; hairs on posterior margins of hind tibiae much shorter than tibial width at apex; hairs on metasomal terga dense; hairs on 1 st and 2 nd terga long, erect to suberect, yellowish gray, those on basal portions of 3rd and 4th terga short, pale to occasionally distinctly fuscous, hairs on 5th tergum including caudal fimbria fuscous, sometimes fading to brown; hairs on posterior margin of 1st tergum downy, not forming a definite band, hairs on posterior margins of 2nd to 4th terga nearly appressed to appressed, forming a quite broad, complete hair band on each tergum; these hair bands uniformly dull yellowish gray in colour.

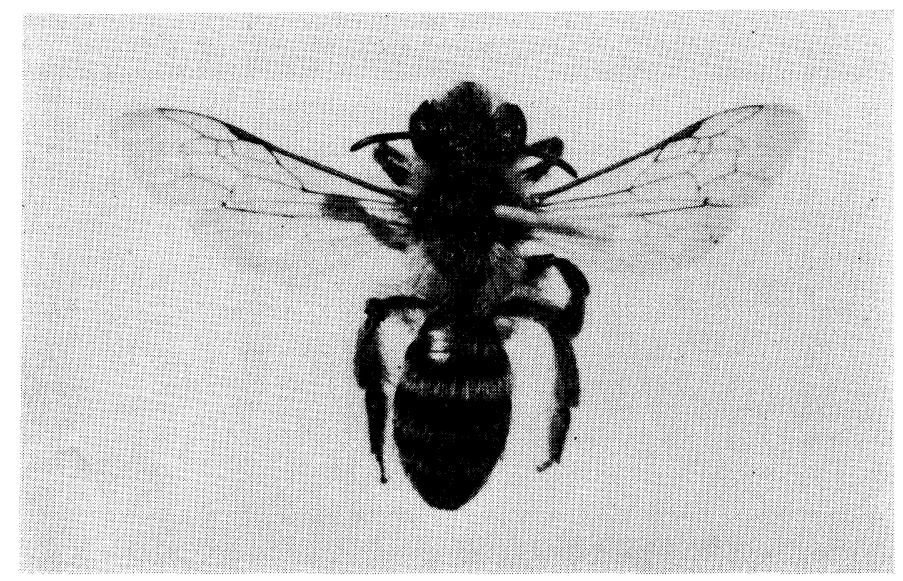

Fig. 134. Andrena(Cnemidandrena) seneciorum sp. nov., female.

Structure : Head moderate; mandibles rather long, robust; malar space very narrow anteriorly, slightly widened posteriorly, about one-fifth as broad as base of mandible at middle; process of labrum distinctly tapering toward apex where deeply notched ; clypeus well convex, weakly tessellate, weakly shiny, rather coarsely and strongly punctate with punctures irregular in distribution at middle; clypeus slightly exceeding line running bases of eyes, its index $2.0: 1.5$; facial quadrangle longer than broad (about $8.6: 7$ ); antennae with 3 rd segment as long as 4th plus 5th; ratio of postocellar width to ocelloccipital distance to postocellar distance to ocellocular distance is $1.6: 2.6: 3.5: 5$; cheeks rounded, its outline very slightly converging posteriorly seen from above, slightly broader than eyes seen in profile, weakly tessellate and indistinctly punctate, feebly shiny. Mesoscutum densely tessellate, rather sparsely and not strongly punctate, dull or nearly so ; scutellum rather broadly nearly smooth basally, sparsely and weakly punctate, feebly shiny, a little roughened and dull apically; propodeum slightly roughened, dull; enclosure more or less well indicated, tessellate, somewhat longitudinally wrinkled basally, nearly dull ; mesopleuron densely tessellate, somewhat coarsely punctate with punctures not so dense, oblique and shallow, dull. Wings with 2nd submarginal cell receiving 1st recurrent vein beyond middle of cell; basal vein distad of nervulus. Legs with mid basitarsi dilated medially, nearly as wide as broad hind basitarsi which is broadest subbasally and tapering toward apex; 
hind tibiae with anterior margins slightly emerginate, widened subapically. Metasomal terga densely tessellate, without distinct punctures, feebly shiny ; posterior depressions of terga broad, not distinctly indicated.

Male : Length 8-9 mm.

Colour: Mandibles reddened apically; flagellum beneath reddish brown ; wings nearly hyaline, distal margins darkened; veins and stigma brownish ; tegulae brown, not transparent; legs piceous, small segments of tarsi yellowish brown; metasoma not at all black, nearly piceous, posterior margins of terga brownish subhyaline to pallid.

Pubescence : Hairs on face, including clypeus, and on scape dense, moderately long, dull white, those on frons, vertex and cheeks above fuscous, not dense; hairs on cheeks below long, dense dull white, more conspicuous than those on the rest of cheeks; hairs on thorax long, dense, yellowish above (especially on mesoscutum), dull white below, mixed with sparse to dense fuscous hairs on posterior portion of mesoscutum ; hairs on legs white to nearly bright ferruginous, without fuscous or blackish ones; hairs on 1st and median portion of 2nd terga long, not specially dense, pale, those on the rest of 2 nd and following terga rather short, dense, mostly brownish to fuscous; hairs on posterior margins of 3rd and 4th terga downy, whitish, forming a more or less evident hair band on each tergum; similar hairs present on posterior margin of 2nd tergum laterally.

Structure: Head large, broader than thorax seen from above; mandibles long, slender, falciform, slightly angulate basally ; malar space very narrow anteriorly, slightly widened posteriorly, about one-fifth as broad as base of mandible at middle ; process of labrum strongly protuberant, deeply notched medially; clypeus scarcely convex, integument of which is more or less obscured by dense covering of hairs, nearly smooth, not specially strongly punctate with punctures irregular in distribution and rather sparse medially, shiny; clypeus distinctly truncate, more or less evidently exceeding line running bases of eyes, its index about 1.5 : 1.5; antennae moderately long, 3rd segment a little less than twice as long as broad, distinctly longer than 4th which is slightly longer than broad and about as long as 5th; ratio of postocellar width to ocelloccipital distance to postocellar distance to ocellocular distance is $1.6: 3.0: 3.1: 6.0$; upper portions of cheeks elongate and angulate posteriorly; cheeks slightly angulate near posterior bases of mandibles; cheeks broad, scarcely receding, broader than eyes seen in profile, narrowly smooth near eyes, tessellate posteriorly, very weakly punctate, weakly shiny; posterior margins of cheeks distinctly keeled. Mesoscutum densely tessellate, except for median portion where narrowly nearly smooth, or very weakly tessellate, with punctures sparse, weaker than those on clypeus; scutellum well convex, broadly nearly smooth but not specially shiny, weakly and sparsely punctate ; propodeum roughened, dull; enclosure ill defined, rather finely tessellate, rugulose to rugose basally; mesopleuron slightly less coarsely sculptured than in propodeum, dull. Wings as in female. Legs slender, without special modification. Metasomal terga densely to weakly tessellate, nearly impunctate, weakly shiny; posterior depressions of terga not well indicated. Genitalia and subgenital sterna as illustrated.

Distribution: Japan (Hokkaido and central Honshu).

Type material : Holotype male, allotopotype female, 3 paratopotype males and 4 paratopotype females, on the flowers of Senecio palmatus Pall., Nukabira, Tokachi, Hokkaido, 1-4. viii. 1953 (Y. Hirashima); 2 paratype females, Nishiashoro, 
Tokachi, Hokkaido, 8. viii. 1955 (Y. Hirashima); paratype male and 3 paratype females, Karuizawa, Nagano Pref., 19. viii. 1950 (R. Ishikawa).

Type dep ositorics: Holo-, allo- and 9 paratypes are in the collection of the Entomological Laboratory, Kyushu University ; 4 paratypes to the collection of R. Ishikawa.

Flower record: Senecio palmatus Pall.
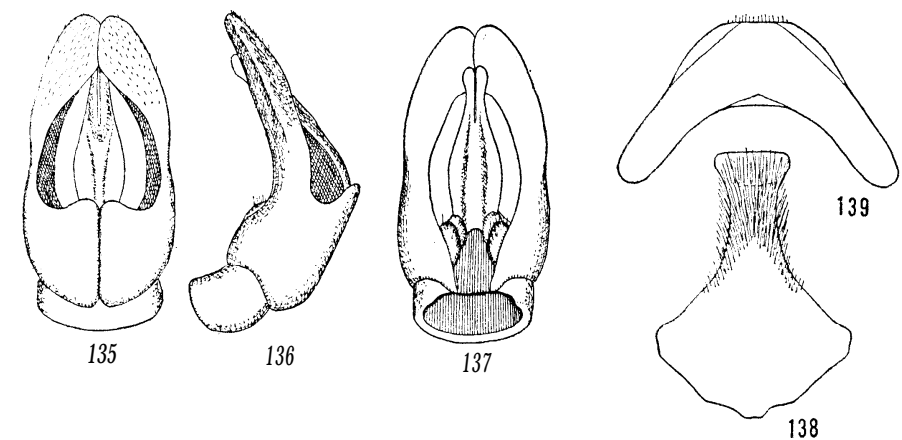

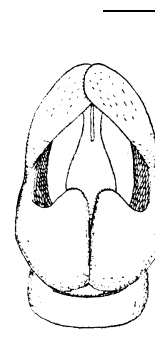

140

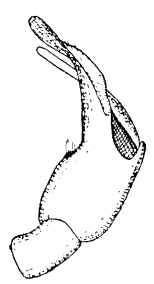

141

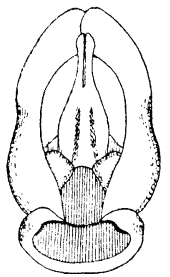

142

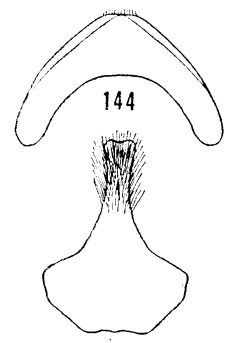

143

Figs. 13j-144. Genitalia and associated structures of male Andrena (Cnemidandrena). Figs. 135-139: seneciorum sp. nov., 135: dorsal view of genitalia, 136: lateral view of the same, 137: ventral view of the same, 138: 8th sternum, 139: 7th sternum; figs. 140-144:mactai sp. nov., 140: dorsal view of genitalia, 141: lateral view of the same, 142: ventral view of the same, 143: 8th sternum, 144: 7th sternum.

\section{(22) Andrena (Cnemidandrena) maetai sp.nov.}

This species is of size of Andrena fuscipes (Kirby) of Europe but is easily separated from it and its allied species by the presence of the blackish hairs on the mesoscutum. This species is apparently a close relative of Andrena seneciorum Hirashima, but is readily separated from the latter by the smaller size, the less emarginate process of labrum, the nearly smooth scutellum and the narrower and denser tergal hair bands in the female, and the broad and not keeled cheeks in the male. 
This species is known only from Tsushima at the present time, and has been collected in October.

Female: Length from 9 to nearly $10 \mathrm{~mm}$.

Colour: Black ; mandibles broadly reddened apically ; bases of mandibles as well as malar spaces reddened; flagellum beneath excepting basal two segments broadly yellowish or pale yellowish brown; wings smoky, distal margins slightly darkened ; veins and stigma brownish; tegulae brownish, nearly subhyaline ; legs piceous; small segments of tarsi brownish; tibial spurs pale; posterior margins of metasomal terga narrowly nearly discolored.

Pubescence: Hairs on head and thorax rather abundant, those on metasoma not specially so; hairs on face, including clypeus, and on cheeks more or less short, white, those on vertex slightly brownish, those on occiput yellowish; facial fovea brownish above, paler below; hairs on thorax above long, pale to pale yellowish brown, mixed with brownish to fuscous hairs on mesoscutum, those on thorax below pale to white; hairs on legs white to brown; trochanteral floccus dull white ; femoral floccus nearly silver white, occasionally indistinctly brownish ; hairs on outer faces of tibiae and basitarsi of mid and hind legs yellowish to slightly brownish, tibial scopa narrowly whitish in front; tibial scopa rather large, compact, composed of more or less long, rather well arranged hairs; hairs on 1st metasomal tergum long, paler, those on following terga short, suberect to nearly appressed, pale and brownish; caudal fimbria brown or fuscous; posterior margins of 2 nd to 4 th terga each with a broad, complete, well indicated band of white, appressed to nearly appressed hairs.

Structure: Head moderate ; mandibles moderately long, robust; malar space very narrow anteriorly, widened posteriorly, about or less than one-fifth time as broad as base of mandible at middle; process of labrum rugulose, narrowing toward apex where slightly emarginate ; clypeus slightly convex, densely tessellate basally and becoming smoother apically, more or less strongly punctate with punctures irregular in distribution and rather sparse medially; clypeus slightly exceeding line running bases of eyes, its index $1.8: 1.2$; facial quadrangle a little longer than broad (about $7.5: 6.8$ ); antennae with 3rd segment a little longer than 4th plus 5th; ratio of postocellar width to ocelloccipital distance to postocellar distance to ocellocular distance is $1.5: 2.0: 3.7: 4.7$; cheeks rounded, a little broader than eyes seen in profile, rather densely tessellate, feebly punctate near eyes. Mesoscutum densely tessellate anteriorly, weakly so and therefore slightly shiny medially, weakly and sparsely punctate with punctures much weaker than those on clypeus; scutellum broadly nearly smooth or weakly tessellate, shiny, scattered with weak punctures, narrowly rougened apically ; propodeum densely tessellate, not roughened, nearly dull ; enclosure quite indistinctly defined, tessellate, narrowly rugose or wrinkled basally ; mesopleuron nearly as coarse as propodeum, dull. Wings with 2 nd submarginal cell receiving 1 st recurrent vein slightly beyond middle of cell; basal vein interstitial with nervulus. Legs with mid basitarsi strongly expanded medially, a little broader than hind basitarsi which is widest subbasally and tapering toward apex; hind tibiae expanded subapically. Metasomal terga rather densely to densely tessellate, nearly impunctate, weakly shiny ; posterior depressions of terga indistinct.

Male: Length less than $8 \mathrm{~mm}$.

Colour: Black; mandibles reddened apically; malar space reddened ; flagellum beneath except basal segment broadly yellowish or pale yellowish brown; wings 
slightly duskly, veins and stigma brownish; tegulae pale brownish subhyaline, darker anteriorly ; legs piceous, tarsi brownish ; abdomen nearly piceous, posterior margins of terga pale yellowish transparent.

Pubescence : Hairs on head and thorax rather abundant but not obscure integument, long, nearly uniformly dull white or slightly yellowish on thorax above, without admixture of blackish ones; hairs on legs white to yellowish; hairs on 1st and median portion of 2nd terga long, whitish, those on the rest of 2nd short, whitish, those on following terga short, brownish; hairs on 6th tergum whitish ; posterior margins of 2nd to 4th terga with sparse white hair fringes laterally; posterior margins of 2 nd to 5th sterna each with a complete fringe of long, curled, silvery hairs.

Structure: Head large, broader than thorax seen from above; mandibles long, slender, falciform, not angulate basally as in preceding species; malar space nearly linear anteriorly, slightly widened posteriorly; process of labrum small, strongly protuberant, excavated beneath ; clypeus hardly convex, broadly nearly smooth medially, rather weakly punctate with punctures rather sparse medially and irregular in distribution ; integument of clypeus somewhat obscured by covering of hairs; clypeus slightly exceeding line running bases of eyes, its index about $1.5: 1.4$; facial quadrangle a little longer than broad (about $7.2: 6.7$ ); antennae moderately long, 3rd segment more than one and one-half times as long as broad, distinctly longer than 4th which is about as long as wide and a little shorter than 5th; ratio of postocellar width to ocelloccipital distance to postocellar distance to ocellocular distance is $1.5: 2.2: 3.7: 5.0$; upper portions of cheeks elongate but not angulate posteriorly seen from above; cheeks much broader than eyes seen in profile, neither carinate posteriorly nor angulate beneath near posterior bases of mandibles, rather broadly smooth and feebly punctate near eyes, tessellate posteriorly. Mesoscutum tessellate anteriorly, nearly smooth and shiny medially, weakly and sparsely punctate ; scutellum well convex, broadly smooth and shiny, scattered with weak punctures, narrowly tessellate anteriorly ; propodeum densely tessellate or nearly roughened; enclosure ill defined, tessellate, narrowly rugose or wrinkled basally; mesopleuron nearly as coarse as propodeum, dull. Wings as in female. Legs slender, without special modification. First metasomal tergum tessellate, following terga weakly so or nearly smooth, indistinctly punctate ; posterior depression indistinct. Genitalia and subgenital sterna as illustrated.

Distribution : Japan (Tsushima).

Type material: Holotype male, allotype female, Mt. Ariake, Tsushima, IO. x. 1953 (Y.Maeta); 3 paratopotype males and 40 paratopotype females, same data as holotype (Y. Maeta).

Type depository: All the types are found in the collection of the Entomological Laboratory, Kyushu University.

Flower record: A number of females has been collected on the flowers of Lactucadenticulata Maxim.

This species is named for the honor of Mr. Yasuo Maeta of Shinshu University.

\section{Subgenus Euandrena Hedicke}

Euandrena Hedicke, 1333, Mitt. Zool. Mus. Berlin, 19 : 212 ; Hirashima, 1952, Mushi, $24: 64$. 
Type-species : Andrena bicolor Fabricius, 1775. (Original designation.)

Diagnosis: The subgenus is characterized by the metasoma being tessellate, impunctate or rarely finely punctate, and more or less hairy with hairs forming an obscure to rather distinct hair band on the posterior margins of intermediate terga, or hair band lacking. The head and thorax usually abundantly hairy. Occasionally the species of Euandrena resemble those of Andrena s. str., but is readily recognizable by the less developed propodeal corbicula and the absence of the ventral projection on the base of mandible.

The subgenus is found in the Old World alone. So far as my study goes, the subgenus is represented at least five species in Japan. Some of them, however, such as hebes and stellaria, are seemed very likely to be a Thysandrena of the New World. Since I do not have enough material of Thysandrena, the interrelationship of Euandrena and Thysandrena is not clear to me.

Description : More or less small to medium-sized species, integument black, occasionally legs partly reddened. Head moderate in size; process of labrum flat and entire in female, except for takachihoi in which it is thickened and emarginate apically, slightly reflected at apex in male; malar space more or less evident; inner margins of eyes subparallel; thorax with or without black pubescence, usually abundantly hairy ; enclosure of propodeum not sharply indicated, slightly roughened to finely sculptured; propodeum outside enclosure as well as mesopleuron shagreened or slightly roughened; fore wings with three submarginal cells; metasoma tessellate, impunctate or rarely weakly punctate, at least more or less hairy, with posterior depressions not distinctly indicated.

Female: Facial fovea rather short, hardly exceeding below line running lower margins of antennal sockets, narrow to rather narrow, with upper end occupying about or less than one-half of distance between eye and lateral ocellus; 3rd antenna1 segment about as long as 4th plus 5th; propodeal corbicula not well developed, with dorsal fringe of long, moderately compact to rather scanty, not downwards curling hairs, interior of corbicula with sparse, fine, hairs nearly throughout, no fringe of hairs anteriorly; trochanteral floccus imperfect, scanty ; tibialscopa usually well developed, composed of long, dense, simple or rarely branched hairs which are rather compact to somewhat loose; mid basitarsi narrow or rarely more or less broad but not dilated medially, subequal to hind basitarsi in width; tibial spurs simple; posterior margins of metasomal terga with or without obscure to rather compact hair fringes.

Male: Clypeus black ; mandibles moderately long, not falciform ; antennae usually long, with 3rd segment at least longer than wide, longer than next segment; cheeks moderate; genitalia small and simple, with parapenial lobe slightly produced and rounded; paramere slender; aedeagus slender, not specially widened basally, apex not sharply pointed, with sides excavated.

\section{(23) Andrena (Euandrena) hebes Pérez}

Andrena hebes Perez, 1905, Bull. Mus. d'Hist. Nat., 1905: 35, female; Cockerell, 1913, Ann. Mag. nat. Hist., (8) 11: 154; Alfken, 1932, Mitt. Deut. ent. Gesell., 3 : 117, female and male ;Uéda, 1954, Trans. Shikoku ent. Soc., 4: 50.

This and the following species, Andrena stellaria sp. nov., are related so closely each other that the separation of them becomes difficult in some worn specimens. This species is primarily recognizable in having the pubescence on the head and 
thorax darker and the metasomal hair bands less evident than in stellaria in both sexes.

This species flys early in spring, and the females have been collected on the flowers of Calendula, Prunus, Bvassica and Stellaria.

Fcmale: Length $8-9.5 \mathrm{~mm}$.

Colour: Black; mandibles reddened apically ; flagellum beneath obscurely brownish; wings slightly brownish subhyaline, with distal margins more darkened; veins and stigma brown; tegulae deep reddish brown posteriorly, blackened anteriorly ; legs occasionally obscurely piceous; tibial spurs ferruginous ; posterior margins of metasomal terga brownish basally to yellowish subhyaline apically.

Pubescence: Head indistinctly narrower than thorax seen from above; mandibles moderately long and stout; malar space rather evident, a little more than one-fourth time as long as base of mandible; process of labrum large, flat, tapering apically with apical margin nearly entire; clypeus well convex, broadly nearly smooth medially, sparsely and more or less distinctly punctate with punctures much sparser and integument much smoother than in Andrenaangustior (Kirby) of Europe, to which hebes slightly resembles; clypeus elongate, distinctly longer than in angustior, well exceeding line running bases of eyes, its index about $1.5: 1 . \bar{j}$; facial quadrangle longer than broad (about $7.3: 3.5$ ); antennae with 3rd segment about as long as 4th plus 5th which are broader than long respectively; facial fovea narrow, not well indicated; frons longitudinally densely striate; ratio of postocellar width to ocelloccipital distance to postocellar distance to ocellocular distance is $1.4: 1.0: 3.5: 3.8$; cheeks receding, slightly broader than more or less slender eyes seen in profile, nearly shagreened posteriorly. Mesoscutum dull, densely tessellate-punctate with punctures considerably much weaker than those on clypeus; scutellum nearly as in mesoscutum with punctures slightly stronger; propodeum roughened, dull; enclosure ill defined, roughened basally, densely tessellate or nearly shagreened, with an indication of weak punctures. Wings with 2nd submarginal cell receiving 1st recurrent vein slightly beyond middle of cell; basal vein slightly distad of nervulus. Legs with hind tibiae slender; mid basitarsi scarcely dilated medially, subequal to hind_ basitarsi in width; tibial spurs normal. Metasoma feebly shiny ; metasomal terga densely tessellate, nearly impunctate; posterior depressions of 2 nd to 4 th metasomal terga rather broad, weakly indicated, slightly more shiny than elsewhere.

Male: Length 7-8 $\mathrm{mm}$.

Colour: Black; mandibles reddened apically ; flagellum brownish beneath ; wings slightly brownish subhyaline, with distal margins slightly more darkened; veins brownish, stigma deep brown; tegulae brown, blackened anteriorly ; legs black with small segments of tarsi slightly brownish; posterior margins of metasomal terga rather broadly brownish basally to pale subhyaline apically.

Plibescence: Hairs on head and thorax long, rather abundant, those on metasomal terga short, not dense; hairs on head nearly all fuscous or sometimes those on apex of clypeus, supraclypeal area, occiput and cheeks below whitish; hairs on thorax variable, occasionally nearly all fuscous or sometimes predominantly whitish with sparse fuscous hairs on mesoscutum, scutellum, propodeum and mesopleuron; hairs on thorax not obscure integument; hairs on metasoma whitish basally, brownish apically ; posterior margins of 2 nd to 4 th metasomal terga with loose white hair fringes; 5th tergum without such hair fringe.

Sincture: Head moderate in size; mandibles slender, moderately long, with 
sharp apices ; malar space about one-fourth time as long as base of mandibles; process of labrum large, notched medially; clypeus well convex, rather sparsely to rather densely and somewhat coarsely punctate, weakly shiny; clypeus with lateral portions well appressed ; clypeus more or less long, well exceeding line

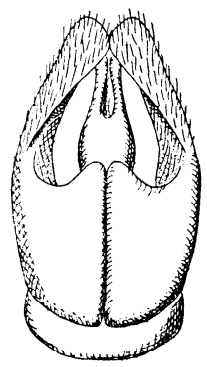

145

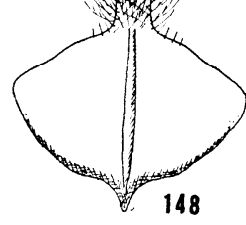

48

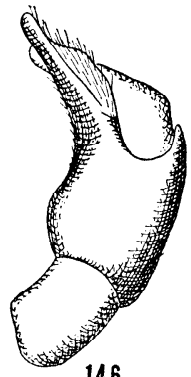

146

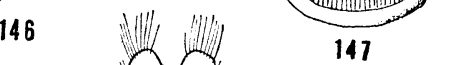

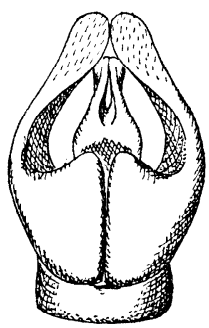

150

153
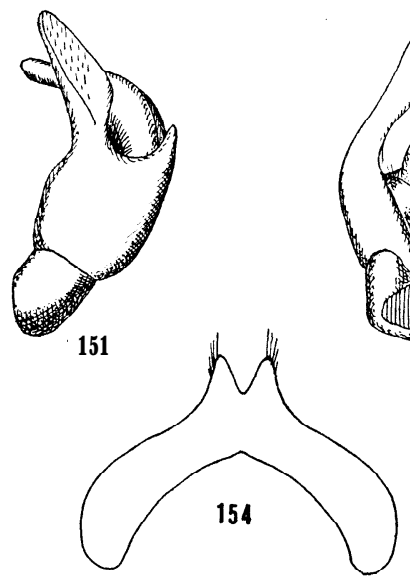

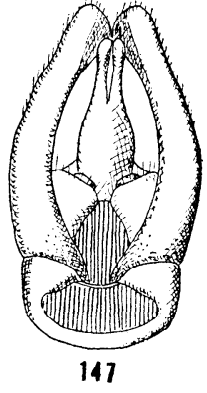

149
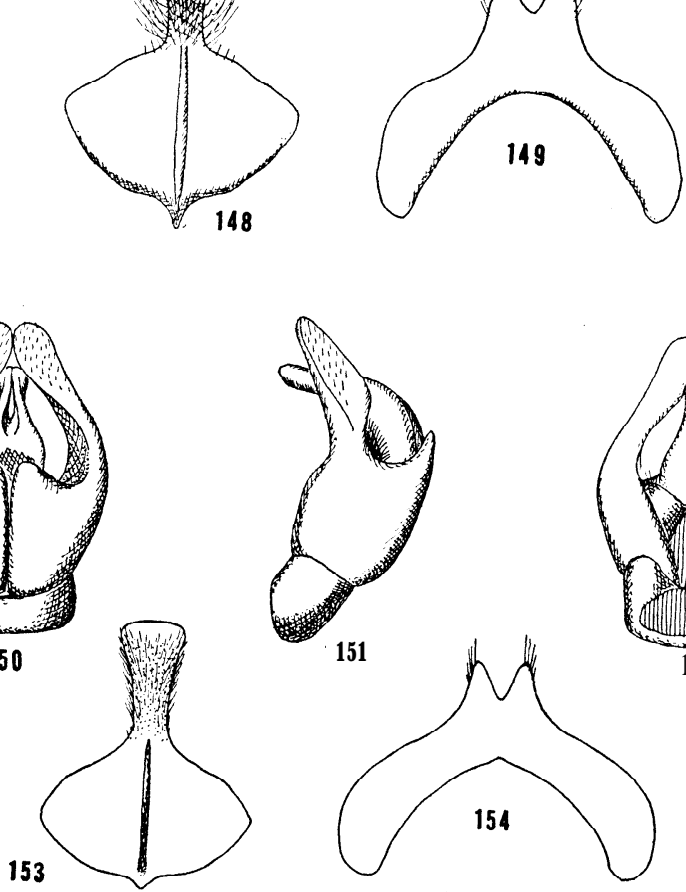

Figs. 145-154. Genitalia and associated structures of male Andrena (Euandrena).

Figs 145-149:hebes Perez, 145: dorsal view of genitalia, 145 : lateral view of the same, 147: ventral view of the same, 148: 8 th sternum, 149: 7th sternum ; figs. 150-154: stellaria sp. nov., 150: dorsal view of genitalia, 151: lateral view of the same, 152: ventral view of the same, 153: 8 th sternum, 154: 7 th sternum. 
running bases of eyes, its index about $1.3: 1.3$; facial quadrangle longer than broad (about 6.5 : 5.3); antennae elongate with 3rd segment longer than broad, slightly longer than 4th which is approximately as long as broad; 5th and following segments longer than broad; ratio of postocellar width to ocelloccipital distance to postocellar distance to ocellocular distance is $1.3: 1.1: 3: 4$; frons densely longitudinally striate; vertex roughened ; cheeks receding, about as broad as eyes seen in profile, nearly roughened posteriorly. Mesoscutum dull, shagreened or nearly roughened with an indication of weak punctures; scutellum as in mesoscutum; propodeum roughened ; enclosure ill defined or occasionally hardly defined, roughened basally or nearly all over; mesopleuron nearly as in mesoscutum. Wings as in femal. Legs slender, as usual. Metasoma elongate, weakly shiny ; metasomal terga densely tessellate, impunctate; posterior depressions of 2 nd to 5th metasomal terga very weakly indicated, slightly smoother than elsewhere. Genitalia and subgenital sterna as illustrated.

Distribution: Japan (Honshu, Shikoku, and Kyushu).

Specimens examined: A long series of specimens were examined. Some of them are listed below.

Honshuı: 1 female, Kashiwabara, Prov. Tanba, 4. iv. 1953 (Y. Yamamoto); 1 female, on Prunus americana, Campus, Shinshu Univ., Ina City, 19-20. iv. 1961 (Y. Maeta):Shikoku: 1 female, Mt. Saragamine, Prov. Iyo. 16. iv. 1952 (T. Ishihara) : Kyushu: 2 females, on flowers of Prunus mume and Calendula arvensis respectively, Fukuoka, 16. iii. 1952 (Y. Hirashima); 2 females, on Stellaria media, Fukuoka, 6. iv. 1952 (Y. Hirashima).

Flower records: As shown above, females of this species have been collected on the flowers of Calendula arvensis L., Prunus mume Sieb. et Zucc., Prunus americana L. var. ausu Maxim., Brassica campestris L. and Stellaria media Cyr.

According to Miyamoto (1960), this species visits the flowers of Taraxacum platycarpum, Veronica caninotesticulata, Omphaloides japonica, Rhododendron spp., Fragaria chiloens is, Brassica campestris, Cardamine flexuosa, Salix yoshinoi, a n d Allium fistulosum.

\section{(24) Andrena (Euandrena) stellaria sp. nov.}

This is sibling species to Andrenahebes Perez. The female of this species is distinguished from that of hebes by the combination of characters such as the malar space a little narrower, the clypeus tessellate (although weakly) medially, the pubescence of the head and thorax much palar, the hair bands of the metasomal terga more conspicuous, and the trochanteral floccus and tibial scopa less developed. The male is only separable from that of hebes in having the mesopleuron slightly less coarsely sculptured, the pubescence of the head and thorax much paler, the thorax usually without blackish hairs and the hair bands of the metasoma more conspicuous.

This species flys early in Spring and primarily associates with the flowers of Brassica.

Female: Length S-9.5 mm.

Coloitr: Black ; mandibles reddened apically; flagellum obscurely brownish beneath; wings slightly paler than in hebes, subhyaline with distal margins slightly darkened; veins brownish, stigma reddish brown; tegulae slightly paler 
than in hebes, reddish brown posteriorly and blackened anteriorly; legs obscure piceous; tibial spurs pale; posterior margins of metasomal terga slightly more broadly brownish than in hebes.

Pubescence : Hairs on head much paler than in hebes, primarily whitish; oc casionally sparse brownish hairs present on frons laterally; facial fovea paler than in hebes, bright brown in some light; hairs on thorax pale fulvous above, becoming whitish below, without admixture of darker ones; hairs on thorax rather dense but not obscure integument; propodeal corbicula similar to hebes; hairs on mesopleuron above long, becoming shorter beneath; hairs on tibiae and tarsi of fore and mid legs paler than in hebes, only slightly brownish; trochanteral floccus very scanty, silvery ; femoral floccus silver white, somewhat dense; tibia1 scopa more or less well developed with long, somewhat loose, silver white hairs; tibia1 scopa slightly brownish above basally; hairs on metasoma short, scanty, whitish; posterior margins of 2 nd to 4 th metasomal terga each with a nearly complete band of rather dense, decumbent, white hairs; posterior margins of 1 st metasomal tergum with similar hairs not forming a distinct band; caudal fimbria pale brown.

Structure: Head indistinctly narrower than thorax seen from above; mandibles moderate or rather slender; malar space narrower than in hebes, about one-fifth time as long as base of mandible; malar space large, nearly trapezoid with apical margin entire ; clypeus well convex, shiny (less shiny than in hebes) somewhat strongly and rather sparsely punctate with a median, longitudinal, flat, weakly tessellate and impunctate space ; clypeus well exceeding line running bases of eyes, its index about 1.7 : 1.5 ; facial quadrangle longer than broad (about 7.7 :6.2); antennae with 3rd segment about as long as next two segments together which are broader than long respectively; facial fovea narrow, with inner margin not sharply indicated ; ratio of postocellar width to ocelloccipital distance to postocellar distance to ocellocular distance is $1.5: 1.0: 3.1: 4.0$; cheeks receding, about as broad as more or less elongate eyes seen in profile, nearly shagreened posteriorly. Mesoscutum dull, slightly less coarsely sculptured than in hebes, nearly shagreened with an indication of small, somewhat roughened punctures; scutellum approximately as in mesoscutum ; propodeum dull, roughened, with an indication of week punctures; enclosure poorly defined, roughened basally ; mesopleuron dull, densely tessellate but hardly roughened. Wings with 2nd submarginal cell receiving 1st recurrent vein about middle of cell; basal vein almost interstitial with nervulus. Legs with hind tibiae slender; mid basitarsi scarcely expanded ; tibial spurs normal. Metasomal terga densely tessellate, dull, almost impunctate ; posterior depressions of terga weakly indicated.

Male: Length less than $7.5 \mathrm{~mm}$.

Colour: Black; mandibles reddened apically ; flagellum beneath brownish to pale brownish or sometimes reddish brown; wings subhyaline with distal margins slightly darkened ; veins brownish, stigma reddish brown; tegulae light reddish brown posteriorly, blackish anteriorly ; legs black, tarsi brownish ; sometimes hind tibiae piceous; posterior margins of metasomal terga brownish basally to narrowly pale transparent apically.

Pubescence : Hairs on head long, white or whitish, mixed with blackish hairs on sides of face, frons and cheeks above; hairs on thorax long, more or less dense, primarily whitish to white, without admixture of blackish hairs or rarely sparse, blackish hairs present on mesopleuron above ; hairs on legs whitish; 
hairs on 1st metasomal tergum rather long,becoming denser and downy near posterior margin; hairs on 2 nd and following terga short, sparse, rather fine ; posterior margins of 2 nd to 4 th metasomal terga with white hair fringes interrupted or obscured medially; posterior margins of 2 nd to 5 th metasomal sterna each with a complete fringe of suberect, silver white hairs.

Structure: Head about as broad as thorax seen from above; mandibles moderately long, rather slender; malar space narrow, about one-sixth time as long as base of mandible; process of labrum large, notched apically; clypeus obscured by covering of hairs, but densely punctate with interspaces weakly tessellate ; clypeus more or less well exceeding line running bases of eyes, its index about $1.4: 1.2$; facial quadrangle longer than broad (about $6.6: 5.2$ ); antennae elongate, with 3rd segment longer than broad, about as long as or a little longer than next segment; 5th and following segments longer than broad; vertex nearly roughened; ratio of postocellar width to ocelloccipital distance to postocella $r$ distance to ocellocular distance is $1.3: 1.4: 2.7: 4$; vertex nearly roughened; cheeks receding, about as broad as eyes seen in profile, nearly shagreened posteriorly. Mesoscutum dull, shagreened with an indication of weak, roughened punctures; scutellum nearly as in mesoscutum; propodeum roughened with enclosure poorly defined, roughened or wrinkled basally; mesopleuron dull, sculptured nearly as in mesoscutum. Wings with 2nd submarginal cell receiving 1 st recurrent vein at or near middle of cell; basal vein almost interstitial. Legs slender, as usual. Metasoma feebly shiny; metasomal terga tessellate, impunctate; posterior depressions of terga weakly indicated. Genitalia and subgenital sterna as illustrated.

Distribution: Japan (Honshu and Kyushu).

Type material: Holotype male, allotopotype female, Fukuoka, Kyushu, 15. iii. 1950 (Y. Hirashima); 8 paratopotype males, 10. iii. 1950 (Y. Hirashima); 3 paratopotype females and 3 paratopotype males, same data as holotype; 3 paratopotype females, 22. iii. 1950 (Y. Hirashima); paratype female and male, Osaka, Honshu, 15. iii. 1915 (T. Esaki); paratype female and male, Toyotama, Nerima, Tokyo, 16. iii. 1951 (R. Ishikawa); paratype female and 3 paratype males, on Salix sp., Campus, Shinshu Univ., Ina City, 6. iv. 1961 (Y. Maeta); paratype male and female, on Prunusmume, same locality as above, 12-19. iv. 1961 (Y. Maeta); 2 paratype females, on Pyrus simonii, same locality as above, 25. iv. 1961 (Y. Maeta).

Type depositories: Hollo-, allo- and 22 paratypes are in the collection of the Entomological Laboratory, Kyushu University : 4 paratypes to the Entomological Laboratory, Kyushu University; 2 paratypes to the collection of R. Ishikawa.

Specimensexamined other than type material: A series of male and female specimens from Honshu and Kyushu were examined.

Flower records: This species has been collected on the flowers of stellaria media (type series), Brassica campestris, Prunus mume and Pyrus simonii.

\title{
(25) Andrena (Euandrena) ruficrus rabicrus Hirashima
}

\author{
Andrcna (Euandrena) ruficrus rabicrus Hirashima, 1957, Mushi, 30 (9): 50.
}

This subspecies was described from the female and yet the male is not known. Since the description of this subspecies, I was able to examine only two female specimens from Mt. Tanigawadake, Honshu.

The female of this species is easily separated from members of that subgenus 
in having the hind tibiae and tarsi clear ferruginous.

Female: Length less than $10 \mathrm{~mm}$.

Colour: Black; mandibles reddened apically; flagellum beneath brownish or dark reddish brown; wings slightly brownish subhyaline, with distal margins a little more darkened; veins and stigma brownish ; tegulae deep reddish brown, blackened anteriorly; legs piceous with hind tibiae and basitarsi clear ferruginous or occasionally the latter darkened, mid tarsi and small segments of hind tarsi yellowish brown or more darkened; posterior margins of metasomal targa rather broadly yellowish subhyaline.

Pubescence : Hairs on head and thorax more or less long and rather abundant, slightly shorter and paler than in ruficrus; hairs on sides of face, frons, vertex and cheeks above fuscous, those on the rest of head dull yellowish brown to whitish; facial fovea dark, appears bright brown in some light; hairs on thorax dull yellowish brown above, becoming whitish beneath, without admixture of darker hairs, not obscure integument; dorsal fringe of propodeal corbicula not well arranged in a compact fringe; interior of corbicular with sparse fine hairs; trochanteral floccus imperfect, scanty, silver white ; femoral floccus dense, silver white; tibial scopa well developed, composed of long, compact or sometimes more or less loose, golden hairs; hairs on hind basitarsi golden; hairs on metasomal terga whitish ; caudal fimbria brown ; posterior margins of metasomal terga with sparse fringes of suberect to decumbent white hairs.

Structure: Head moderate in size; mandibles rather slender; malar space narrow but evident, about one-three time as long as base of mandible; process of labrum transverse, flat, with apical margin entire; clypeus well convex, weakly to very weakly tessellate, so that more shiny than in ruficrus, rather weakly to moderately punctate with punctures subcontiguous to two or three puncture widths apart, without longitudinal impunctate line; punctures on clypeus distinctly sparser than in ruficrus; clypeus slightly exceeding line running bases of eyes, its index about 2 : 1.4; facial quadrangle longer than broad (8:6.8); antennae with 3rd segment about equal to 4th plus 5th which are broader than long respectively ; facial fovea short, not exceeding below beyond line running lower margins of antennal sockets, separated from eye margins by a narrow punctate space ; frons densely longitudinally striate ; vertex shagreened ; ratio of postocellar width to ocelloccipital distance to postocellar distance to ocellocular distance about $1.5: 1.3: 3.5: 4.7$; cheeks rather rounded, not distinctly receding, about as broad as eyes seen in profile, densely tessellate posteriorly. Mesoscutum dull, nearly shagreened with more or less roughened punctures; punctures on mesoscutum sparser and more evident than in ruficrus; scutellum nearly as in mesoscutum with punctures weaker and sparser; propodeum dull, roughened with an indication of roughened punctures ; enclosure rather well indicated, densely reticulate, wrinkled basally ; sculpture of enclosure coarser than in ruficrus; mesopleuron dull, shagreened with an indication of roughened punctures. Wings with 2nd submarginal cell receiving 1st recurrent vein about or before middle of cell; basal vein almost interstitial with nervulus. Legs with hind basitarsi rather slender ; mid basitarsi more or less subparallel-sided, scarcely expanded medially, subequal to hind basitarsi in width; tibial spurs normal. Metasomal terga more shiny than in ruficrus, tessellate, with an indication of weak and sparse punctures ; posterior depressions of terga weakly indicated.

Male: Unknown. 
Distribution: Japan (Hokkaido and northern and central Honshu). The nominate form is found in Europe.

Specimens examined: Two females, Mt. Tanigawadake, Gumma Pref., 14. vi. 1952 (R. Ishikawa); 1 female, Jozankei, near Sapporo, Hokkaido, 18. v. 1910 (S. Matsumura).

Flower record: No flower record is available for this subspecies. It is known that Andrenaruficmes visits the flowers of Salix in Europe.

Parasite: Nomada obscura Zett. is known as a parasite of this species in E u rope.

\section{(26) Andrena(Euandrena) takachihsi sp. nov.}

Unfortunately this species is known from the female. The female of this species is easily distinguished from members of the subgenus in having the tibial scopa entirely fuscous. It is further distinct by the process of labrum about as long as broad with the apical margins slightly to distinctly notched. The general appearance of the female is very close to that of European Andrenaangustior (Kirby), but the latter has the tibial scopa golden and differs in many details.

This species fys in Autumn. Female of this species associates with the flowers of Lactuca and Aster. According to the collection data, a series of females have been collected from August to September in the mountainous regions of Honshu and Kyushu.

Female: More or less slender, length $9-10 \mathrm{~mm}$.

Colour: Black ; mandibles reddened apically ; flagellum beneath piceous or reddish brown; wings very slightly brownish subhyaline with distal margins slightly more darkened; veins and stigma brownish; legs piceous or brownish; tibial spurs yellowish brown ; metasoma occasionally partly piceous, with posterior margins of metasomal terga rather broadly brownish basally to pale transparent apically.

Pubescence: Hairs on head rather short, not specially dense, primarily dull and whitish, mixed with fuscous hairs on sides of face, frons, vertex and cheeks above, or sometimes hairs on head predominantly brownish; facial fovea nearly fuscous, appears bright in some light; hairs on thorax rather long and dense but not obscure integument, dull, yellowish above, becoming whitish below; dorsal fringe of propodeal corbicula scanty, not well arranged; interior of corbicula with sparse, fine hairs; hairs on legs primarily brownish to fuscous; trochanteral floccus short, scanty, whitish ; femoral floccus rather dense, slightly silvery; tibial scopa large, composed of long, somewhat loose, more or less coarse, fuscous hairs ; metasoma more hairy than in hebes and stellaria: hairs on metasoma whitish basally, becoming brownish apically, with caudal fimbria brown to fuscous; posterior margins of 2 nd to 4 th metasomal terga each with a nearly complete band of loose, decumbent, whitish hairs; posterior margin of 1st tergum with suberect, more or less coarse whitish hairs not forming a band.

Structure: Head about as broad as thorax seen from above, more or less round in front views; mandibles moderately long and robust, malar space very narrow, about one-eight time as long as base of mandible; process of labrum about as long as broad, reflected and emarginate at tip; clypeus moderately well convex, feebly shiny, weakly tessellate, strongly and more or less coarsely 
punctate with punctures contiguous to several puncture widths apart; punctures on clypeus much stronger than in angustior; clypeus slightly exceeding line running bases of eyes, its index about 1.9: 1.3; facial quadrangle longer than broad (about $8: 6.3$ ); antennae with 3rd segment longer than 4th plus 5th which are distinctly broader than long respectively, 6th approximately as long as broad; facial fovea narrow, short, separated from eye margin by a punctate space, with lower end not exceeding below line running lower margins of antennal sockets; upper end of facial fovea not sharply indicated; frons distinctly longitudinally striate with an indication of weak punctures; vertex shagreened; ratio of post ocellar width to ocelloccipital distance to postocellar distance to ocellocular distance about $1.6: 2.2: 3.5: 4.3$; cheeks convex, rounded, about as broad as eyes in profile, punctate-tessellate. Mesoscutum nearly dull, tessellate, more or less distinctly and rather densely punctate with punctures much weaker than those on clypeus; scutellum less punctate than in mesoscutum; propodeum dull, roughened ; enclosure somewhat distinctly defined, densely reticulated and occasionally rugose basally; mesopleuron dull, nearly shagreened, almost impunctate or with an indication of shallow, roughened punctures. Wings with 2nd submarginal cell receiving 1 st recurrent vein slightly beyond middle of cell; basal vein about interstitial or slightly distad of nervulus. Legs with mid basitarsi scarcely expanded medially, subequal to hind basitarsi in width; tibial spurs normal. Metasoma weakly to occasionally more or less well shiny; metasomal terga very weakly tessellate with very weak, sparse punctures or occasionally nearly impunctate ; posterior depressions of metasomal terga hardly indicated medially.

Variation: Specimens from Honshu differ from the holotype from Kyushu in having the vertex less convex in front view, so that the outline of the head not rounded as in the holotype, the ocelloccipital distance shorter, about as long as the postocellar width, the punctures on the clypeus weaker and the pubescence on the head darker, and occasionally the metasoma smoother and more shiny. It seems probable that they may represent a distinct species but I hesitate to describe it at the present time.

Male: Unknown.

Distribution: Japan (Hokkaido, Honshu, and Kyushu).

Typematerial: Holotype female and paratopotype female, on the flowers of Aster indicus L., Mt. Hikosan, Prov. Buzen,14. x. 1959 (Y. Hirashima); paratype female, Jozankei, near Sapporo, Hokkaido, 10. ix. 1915 (S. Matsumura); 4 paratype female, Karuizawa, Nagano Pref., 16-26. viii. 1950 (R. Ishikawa); paratype female, same locality as above, 1. ix. 1950 (R. Ishikawa); 5 paratype females, Kamikochi, Nagano Pref., 4-9. viii. 1957 (R. Ishikawa) ; paratype female, on Lactucadenticulata Maxim., Asamo, Tsushima, 5. 1959 (Y. Hirashima).

Type depositories: Holotype and 8 paratypes are in the collection of the Entomological Laboratory, Kyushu University ; 1 paratype to the Entomological Laboratory, Hokkaido University; 4 paratypes to the collection of R. Ishikawa.

Flower records: Females of this species have been collected on Lactucadenticulata Maxim. and Asterindicus L. as recorded above.

This species is named for the memory of the late Baron Nobumaro Takachiho who is the father of the entomology of Kyushu. 


\section{Subgenus Gymnandrena Hedicke}

Gymnandrena Hedicke, 1933, Mitt. 2001. Mus. Berlin, 19: 213 ;Lanham,1949, Univ. Calif. Pub. Ent., 8: 221; Hirashima, 1952, Mushi, 24: 65 ; Hirashima, 1957, Mushi, 30: 59.

Type-species: Apis thoracica Fabricius, 1775. (Original designation.)

Diagnosis : The subgenus is composed of medium-sized to large species. The process of the labrum of the female is large, flat, usually only slightly emarginate or entire, or unsually deeply so in Andrena okabei Hirashima and Andrena thoracica (Fabricius), the type species of the subgenus. The broad metasoma of the female is scanty of hairs, with or without appressed hair bands. The dorsal face of propodeum as well as the enclosure is coarsely sculptured or occasionally the apical portion of the latter is finely sculptured. The propodeal corbicula is rather well developed, the trochanteral floccus imperfect and dense and the tibial scopa well developed, compact.

The American subgenus Bythandrena Lanham ( = Cryptandrena Lanham, 1949) is very close to Gymnandrena. It is only separable from the latter in having the complete trochanteral floccus of the female and the expanded paramere of the male genitalia.

Gymnandrena is found in both the Old and New Worlds. The East Asian species of the subgenus have been revised by me in 1957. Since then, a single species Andrenacdashigei Hirashima, has been described from the Amami-Oshima Islands.

Since the descriptions of Hedicke (1933), Lanham (1949) and Hirashima (1952 and 1957) have been presented, no attempt will be made in this paper to describe the subgenus.

\section{(27) Andrena (Gymnandrena) watasei Cockerel}

Andrcna zvatasei Cockerell, 1913, Ann. Mag. nat. Hist., (8) 11: 187; Yasumatsu, 1941, Peking nat. Hist. Bull., 15: 281; Uéda, 1954, Trans. Shikoku ent. Soc., 4: 50.

Andrena azarearum Cockerell, 1930, Ann. Mag. nat. Hist., (10) $5: 115$.

Andicna (Gymnandrena) watasei Hirashima, 1957, Mushi, 30 (10) : 66.

This species is unique among our species of the subgenus Gymnandrena in having the black pubescence on the mesoscutum, so that the recognition of it is easy.

This species appears once a year. Females of this species have been collected in April and May, on the flowers of Brassica and Ranunculus. I recorded this species from Honshu, Shikoku and Kyushu in 1957. Since then, I was able to examine two male specimens from Hokkaido. Thus watasei is known from four main islands of Japan at the present time.

Female : Length $12-14 \mathrm{~mm}$.

Colour: Black ; mandibles reddened apically; flagellum obscurely brownish beneath; wings slightly brownish subhyaline with distal margins distinctly darkened ; veins brown, stigma more dark; tegulae deep brown, nearly blackish; legs black or sometimes piceous with tibiae and tarsi reddish brown; tibia1 spurs ferruginous; metasoma deep black with posterior margins of terga narrowly brownish. 
Pubescence: Hairs on head rather short to moderately long, not specially dense, whitish on clypeus, supraclypeal and antennal regions, occiput and cheeks, and blackish on sides of face, frons, vertex and cheeks above near eyes; hairs on mesoscutum and scutellum rather short to moderately long, not obscure integument, primarily blackish medially; hairs on the rest of thorax whitish or white, dorsal fringe of propodeal corbicula well developed, composed of long, dense, well arranged hairs; interior of corbicula with coarse, simple, silver white hairs; hairs on trochanters and femora white, those on tibiae and tarsi predominantly brownish ; trochanteral floccus imperfect, rather dense ; femoral floccus dense, silver white; tibial scopa dense, composed of moderately long, rather coarse, well arranged, simple hairs ; tibial scopa brownish to fuscous, narrowly silver white in front; disc of 1st metasomal tergum nearly bare; hairs on base and sides of 1st, those on sides of 2 nd and following terga whitish; cilia on 2nd and following terga brownish ; caudal fimbria nearly black; posterior margins of 2 nd to 4 th metasomal terga with white hair fringes or bands of dense, short, appressed hairs; band of 4th nearly complete.

Structure: Head about as broad as thorax seen from above, moderately thick; mandibles moderately long and robust; malar space evident, about or less than one-fifth time as long as base of mandible; process of labrum trapezoid, weakly notched apically ; clpyeus well convex, shiny, strongly and densely punctate with an indication of median, longitudinal, raised, impunctate space ; clypeus slightly exceeding line running bases of eyes, its index about 2.2 : 1.6; facial quadrangle slightly longer than broad (about $9.6: 8.8$ ); facial fovea large, not sharply indicated, separated from eye margin by a punctate space; antennae with 3 rd segment about equal to next two segments together; 4th segment approximately as long as broad or a little broader than long, 5th indistinctly longer than broad; vertex roughened; ratio of postocellar width to ocelloccipital distance to postocellar distance to ocellocular distance about $1.8: 3: 4: 6.5$; cheeks rounded, more or less convex, broader than eyes seen in profile, nearly shagreened posteriorly. Mesoscutum nearly shagreened anteriorly, laterally and posteriorly, nearly smooth with enamel-like lustre subposteriorly, with somewhat weak, more or less roughened punctures which are weaker than those on clypeus; scutellum shiny, punctate nearly as in mesoscutum; propodeum nearly dull, strongly roughened ; enclosure usually well indicated, granulate, wrinkled basally, mesopleuron roughened but less coarsely sculptured than in propodeum, with roughened punctures. Wings with 2nd submarginal cell receiving 1 st recurrent vein about middle of cell; basal vein interstitial or slightly distad of nervulus. Legs with mid basitarsi slightly expanded medially, subequal to hind basitarsi in width; tibial spurs normal. Metasoma wealkly to occasionally rather distinctly shiny; 1st tergum nearly smooth, densely punctate with punctures much smaller than those on mesoscutum; 2nd and following terga nearly smooth or indistinctly tessellate, densely punctate with punctures a little finer than those on 1st: posterior depressions of 2 nd to 4 th terga very broad, weakly indicated medially, weakly punctate.

Male: Length 10-11 mm., occasionally a little larger.

Colour: Mandibles reddened apically ; occasionally malar space piceous; flagellum except for 1st segment brownish or reddish brown beneath; wings subhyaline with distal margins slightly darkened; veins and stigma reddish brown or the latter alone brownish ; legs nearly piceous with tibiae and tarsi obscurely to distinctly reddish brown; tibial spurs pale ferruginous; posterior margins of 
metasomal terga reddish brown or brownish subhyaline.

Pubescence : Hairs on clypeus and supraclypeal and antennal regions long, dense, white, those on the rest of head sparser; hairs on sides of face, frons, cheeks near eyes blackish ; occasionally blackish hairs present on clypeus; hairs on thorax long, abundant, nearly dull white, occasionally intermixed with sparse blackish ones on mesoscutum and scutellum; hairs on legs and metasoma primarily white; posterior margins of 2nd to 4th, occasionally to 5th metasomal terga with white fringes of short, not specially dense hairs; hairs on 6th tergum yellowish.

Struc ture: Head slightly broader than thorax seen from above, rather transverse in front view; mandibles long, more or less slender, with sharp apices; malar space evident, about one-fourth time as long as base of mandible; process of labrum transverse, convex, weakly notched apically or nearly entire; clypeus nearly dull, strongly convex medially, rather strongly to strongly, densely rugosopunctate ; paraocular areas coarsely sculptured ; antennae with 3rd segment slightly longer than broad, about as long as or a little longer than 4th which is a little longer than broad and slightly shorter than 5th; vertex well convex and much exceeding line running summits of eyes seen in front, only slightly arched; ratio of postocellar width to ocelloccipital distance to postocellar distance to ocellocular distance is $1.5: 2.5: 3.5: 5.8$; facial quadrangle about as long as broad (about 7.8 : 7.4); clypeus only slightly exceeding line running bases of eyes, its index about $1.8: 1$; cheeks broader than eyes seen in profile, not rounded as in female, nearly shagreened posteriorly. Mesoscutum tessellate, shagreened anteriorly, with more or less dense to rather sparse, roughened punctures which are slightly weaker than those on clypeus; scutellum with punctures weaker than those on mesoscutum; propodeum dull, strongly roughened ; enclosure rather well indicated, granulate, wrinkled basally; mesopleuron roughened with an indication of roughened punctures, slightly less coarsely sculptured than in propodeum. Wings as in female. Legs slender, as usual. Metasomal terga smooth or nearly so, shiny, weakly and sparsely punctate; posterior depressions of terga not well indicated.

Distribution: Japan (Hokkaido, Honshu, Shikoku and Kyushu).

Spccimens examined: A long series of specimens were examined. Out of them, only two specimens from Hokkaido are recorded here : 1 male, Ashorobuto, Ashorogun, 23. v. 1957 (M. Takahashi); 1 male, Nibushi, Lake Kuccharo, 1. vi. 1957 (M. Takahashi).

Flower records: I collected a series of females on the flowers of Brassica campestris L. and Ranunculus acris L. var. japonicus Maxim.

\section{(28) Andrena (G ymnandrena) wulungshanensis Y asumatsu}

Andrena (Glyphandrena) wulungshanensis Yasumatsu, 1935, Insects of Jehol, 8:2, 35; Okabe, 1932, Trans. Kansai ent. Soc., (8): 12; Yasumatsu, 1941, Peking nat. Hist. Bull., 15: 282; Yasumatsu, 1947, Mushi, $18: 32$.

Andrcna (Gymnandrena) wulungshanensis Hirashima, 1957, Mushi, 30 (10):65.

This species was originally described from Jehol, Manchuria, and was recently recorded by me from Japan where, so far as known, it is one of the rarest species of Andrena. This is a very remarkable species. The recognition of it is very easy owing to the large size, the presence of the grayish hairs on the 
head and thorax, the broad metasoma of the female, the dark wings of the male, and the presence of the lateral hair fringe on the metasoma.

According to the collecting data, this species has been collected from August to September in Japan and in August in Manchuria. No flower record is available for this species.

Female: Length $14-15 \mathrm{~mm}$.

Colour: Black; mandibles reddened apically; flagellum beneath brownish or reddish brown; wings slightly smoky with distal margins but little darkened; veins and stigma brownish; tegulae deep reddish brown ; legs piceous; tibial spurs brownish or deep reddish brown; posterior margins of metasomal terga brownish.

Pubescence: Hairs on head rather short, not specially dense, primarily dull white except for brownish hairs on sides of face, frons, vertex and cheeks near eyes; facial fovea bright brown in some light ; hairs on thorax primarily dull white, sparsely intermixed with brownish hairs on mesoscutum; hairs on mesoscutum rather short, sparse posteriorly, rather coarse anteriorly; similar hairs present on scutellum and metanotum; dorsal fringe of propodeal corbicula moderately well developed ; interior of corbicula with coarse, sparse, silver white hairs; hairs on trochanters and femora of fore leg primarily white, those on the rest of legs fuscous except for femoral floccus which is silvery in front; trochanteral floccus sometimes whitish, imperfect, scanty ; femoral floccus dense and long; tibial scopa well developed, composed of rather short to moderately long, coarse, simple hairs ; metasoma scanty of hairs; posterior depressions of 2 nd to 4 th metasomal terga with large lateral fringes of nearly appressed snow white hairs; caudal fimbria fuscous; hairs on metasomal sterna primarily brownish.

Structure: Head about as broad as or indistinctly narrower than thorax seen from above, more or less round in front view; mandibles moderately long, rather slender; malar space nearly obsolescent or slightly windened posteriorly ; process of labrum transverse, with apical margin entire or slightly emarginate; clypeus well convex, tessellate, densely and coarsely rugoso-punctate with punctures slightly weaker than in Andrena okabei okabei Hirashima and Andrena parathoracica Hirashima; clypeus slightly exceeding line running bases of eyes, its index about $2.8: 1.5$; facial fovea long, not specially wide, separated from eye by a punctate, raised space; antennae with 3rd segment fairly longer than next two segments taken tegether but shorter than next three together; vertex just behind ocellar region nearly roughened ; ratio of postocellar width to ocelloccipital distance to postocellar distance to ocellocular distance about 2:4:4:7; cheeks slightly broader than large eyes seen in profile, rather rounded, weakly tessellate with weak punctures. Mesoscutum shagreened with roughened punctures or nearly roughened anteriorly, weakly tessellate or nearly smooth and sparsely and more or less weakly punctate posteriorly with punctures much more regular in form and weaker than those on clypeus; scutellum nearly as in mesoscutum ; propodeum rather short, coarsely sculptured ; enclosure large, well indicated, strongly and irregulary wrinkled nearly all over; mesopleuron tessellate with roughened punctures, slightly less coarsely sculptured than anterior portion of mesoscutum. Wings with 2nd submarginal cell receiving 1 st recurrent vein about middle or slightly before middle of cell; basal vein distad of nervulus. Legs with mid basitarsi slender, hardly expanded medially, subequal to hind basitarsi in width; tibia1 spurs unmodified. Metasoma specifically broad ; metasomal terga nearly 
smooth, with weak, rather irregular punctures which are slightly weaker than those on posterior portion of mesoscutum; posterior depressions of metasomal terga broad, well indicated, microscopically punctate.

Male: Length 12-13 $\mathrm{mm}$.

Colour: Black ; mandibles reddened apically ; flagellum beneath brownish or reddish brown; wings darker than in female, brownish with distal margins more darkened; veins and stigma brown or sometimes the latter reddish brown; tegulae piceous or deep reddish brown; legs nearly black with tarsi or sometimes further hind tibiae reddened; tibial spurs brownish; posterior margins of metasomal terga obscurely brownish.

Pubescence: Hairs on face including clypeus rather short, abundant and obscure integument, dull white as well as those on the rest of head; hairs on thorax rather short to more or less long, somewhat abundant, uniformly dull white, without admixture of darker ones; hairs on trochanters and femora of all legs whitish, those on tibiae and tarsi fuscous; hairs on metasoma rather short to short, not dense, whitish, without darker ones except for brownish hairs on 6th tergum; posterior depressions of 2 nd to 5 th metasomal terga with loose white hair fringes, those of 2 nd and 3 rd lateral.

Structure: Head slightly broader than thorax seen from above, subquadrate in front view; mandibles rather long, more or less slender; malar space nearly obsolescent, slightly windened postoriorly ; process of labrum transverse, convex, only slightly emarginate apically ; clypeus strongly convex, densely and more or less coarsely rugoso-punctate; clypeus only slightly exceeding iine running bases of eyes, its index about $3: 1$; facial quadrangle longer than broad (about $10.8: 8.5$ ); antennae with 3rd segment about twice as long as broad, slightly shorter than th plus 5th; 4th segment about as long as or indistinctly broader than long, 5 th a little longer than broad; facial fovea indistinctly indicated with short brownish hairs above; vertex nearly roughened; ratio of postocellar width to ocelloccipital distance to postocellar distance to ocellocular distance about $2: 1.1$ : 4.2: 7.2 ; cheeks about as broad as large eyes seen in profile, receding, shiny, weakly punctate. Mesoscutum tessellate with roughened punctures anteriorly, smooth with more or less strong to occasionally rather weak, and moderately dense punctures posteriorly, shiny ; scutellum slightly convex, punctured almost as in mesoscutum; propodeum rather short, very coarsely sculptured; enclosure ill defined, as coarsely sculptured as dorsal face of propodeum; mesopleuron tessellate with roughened, more or less strong punctures. Wings nearly as in female. Legs slender, as usual. Metasoma shiny; punctures on metasomal terga about as large and coarse as those on mesoscutum; microscopical fine punctures scattered between them; posterior depressions of terga distinct, finely punctate. Genitalia and subgenital sterna as illustrated.

Distribution: Inner Mongolia, Manchuria and Japan (Honshu).

Flower data: None.

\section{(29) Andrena (Gymnandrena) parathoracica Hirashima}

A ndrena (Gymnandrena) parathoracica Hirashima, 1957, Mushi, 30 (10) : 63.

This is one of the largest species of the subgenus Gymmandrena, and the recognition of it is easy. It is characterized in having the thorax with fulvous 
pubescence and the metasoma deep shiny black, lacking any trace of tergal hair bands. The female of this species is close to Andrenacrassepunctata Cockerell, which is known from China and Korea, but is easily separated from it in having the white pubescence on the hind trochanters, the stronger punctures on the metasoma, etc. It is undoubtedly more close to European Andrena nitida Geof. froy, but is readily distinguished from the latter by the punctures on the clypeus more stronger, the hairs on the thorax shorter and sparser, the mesoscutum more smooth and more shiny posteriorly, and the punctures on the intermediate metasomal terga, especially those on the 3rd and 4th, more dense and finer. The male is easily recognized by the combination of characters such as the more or less large head, the abundant fulvous pubescence on the thorax and the shiny metasoma.

This species appears once a year. Females of this species have been collected from April to June. One of the nesting sites of this species was found at Aburayama, Fukuoka, by Mr. Toyohei Saigusa in 1959. The results of the excavations of nests were presented elsewhere in this paper.

Female: Length $13-14 \mathrm{~mm}$.

Colour: Black ; mandibles obscurely reddened apically ; flagellum beneath obscurely brownish; wings strongly brownish with distal margins more darkened; veins brown, stigma more darkened ; legs black with tarsi piceous; tibial spurs deep reddish brown; metasoma deep shiny black with posterior margins of metasomal terga narrowly slightly brownish.

Pubescence: Hairs on head short to more or less long, not specially dense, pale or pale fulvous on clypeus, antennal regions, occiput and cheeks, fuscous on sides of face, frons, vertex and cheeks, near eyes; facial fovea blackish; hairs on thorax bright fulvous above in fresh specimens, becoming paler beneath; thorax without black hairs but occasionally sparse brownish hairs present on mesoscutum and scutellum ; dorsal frings of propodeal corbicula long, dense, pale fulvous ; interior of corbicula with coarse, simple, silvery hairs; hairs on trochanters a.nd femora of all legs primarily white to whitish, those on tibiae and tarsi fuscous; trochanteral floccus imperfect, rather dense ; femoral floccus especially dense, with hairs on anterior margins branched; tibial scopa dense, composed of rather short, coarse, blackish hairs; metasoma scanty of hairs with discs of 1st and 2nd terga bare; hairs on sides of 1 st tergum pale, those on following terga brownish to blackened; caudal fimbria black,

Structure: Head moderate in size, somewhat transverse in front view: mandibles moderately long, rather slender apically ; malar space well indicated, about onefourth time as long as base of mandible; process of labrum more or less small, slightly reflected and entire apically; clypeus well convex, slightly shiny, strongly rugoso-punctate, without any trace of median, longitudinal, impunctate space ; clypeus moderately exceeding line running bases of eyes, its index about $2.5: 2$; facial quadrangle slightly longer than broad (about 11: 10); facial fovea long, wide, separated from eye by a punctate space; antennae with 3rd segment about equal to 4th plus 5th; vertex narrowly convex behind ocellar region, nearly roughened; ratio of postocellar width to ocelloccipital distance to postocellar distance to ocellocular distance about $2: 3.5: 3.5: 7.3$; cheeks slightly broader than eyes seen in profile, rounded above, receding below, densely tessellate posteriorly, very weakly punctate near eyes. Mesoscutum densely and more or less strongly punctate with punctures on anterior portion roughened, weaker than those on 
clypeus ; scutellum nearly as in mesoscutum ; propodeum dull, strongly roughened; enclosure well indicated, dull, granulate, finely wrinkled basally ; mesopleuron tessellate with dense, roughened punctures, only slightly shiny. Wings with 2nd submarginal cell receiving 1st recurrent vein about or a little before middle of cell; basal vein about interstitial. Legs with mid basitarsi scarcely expanded medially, a little narrower than hind basitarsi; tibia1 spurs mormal. Metasoma shiny; 1st tergum smooth, densely punctate with punctures much weaker than

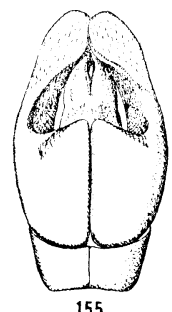

155

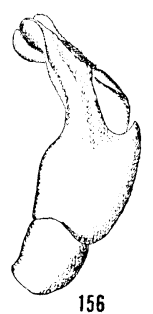

156

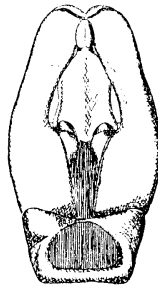

157

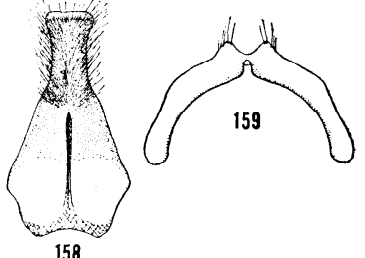

158

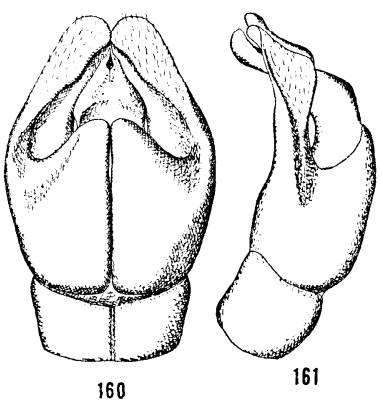

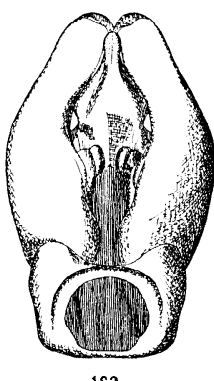

162

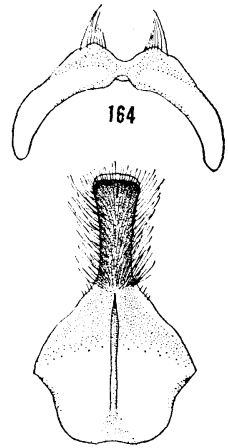

163
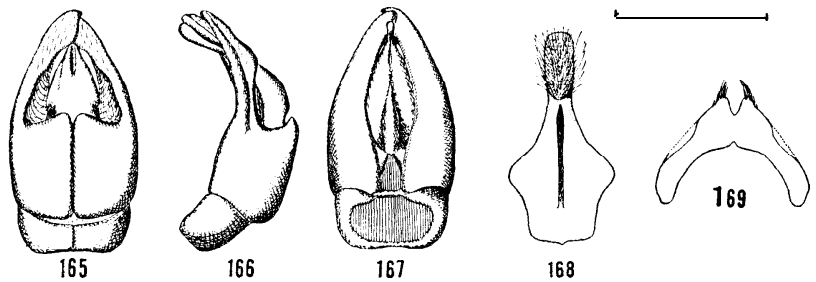

Figs. 155469. Genitalia and associated structures of male Andrena (Gymnandrena).

Figs. 155-1 59: watasei Cockerell, 155: dorsal view of genitalia, 156: lateral view of the same, 157: ventral view of the same, 158: Sth sternum, 159 : 7th sternum; figs. 160-164 : parathoracica Hirashima, 160: dorsal view of the genitalia, 161: lateral view of the same, 162: ventral view of the same, 163: 8th sternum, 164: 7th sternum; figs. 165-169 :edashigei Hirashima,

165 : dorsal view of genitalia, 166: lateral view of the same, 167: ventral view of the same, 168:8th sternum, 169: 7th sternum. 
those on mesoscutum; basal portions of 2 nd and 3 rd metasomal terga more densely and slightly more finely punctate than in 1st tergum; posterior depressions of 2 nd to 4 th terga very broad, microscopically punctate.

Male: Length 14-12 mm.

Colour : Black ; mandibles piceous apically ; flagellum obscurely brownish beneath; wings much paler than in female, slightly brownish subhyaline with distal margins somewhat distinctly darkened; veins and stigma brownish or sometimes the latter alone reddish brown; legs nearly black or slightly piceous with tibiae and tarsi more reddened or occasionally deep reddish brown; meta soma shiny black with posterior margins of metasomal terga reddish brown.

Pubescence: Hairs on face including clypeus long, abundant, dull pale fulvous, intermixed with sparse to somewhat dense brown ones; hairs on occiput and cheeks also dull pale fulvous; hairs on sides of face, frons and cheeks near eyes brown to fuscous; hairs on thorax long, abundant, fulvous above, paler below, without admixture of brownish ones ; hairs on legs primarily yellowish ; metasoma rather scanty of hairs; hairs on 1st to 3rd terga short, pale, those on the rest of terga primarily brownish to brown.

Structure: Head broader than thorax seen from above, subquadrate seen in front; mandibles long, rather robust, with sharp apices; malar space well indicated, about one-fourth as long as base of mandible; process of labrum rather small, weakly notched apically or nearly entire; clypeus strongly convex medially, strongly and rather coarsely rugoso-punctate, weakly shiny ; clypeus only slightly exceeding line running bases of eyes, its index about 2.5 : OS; facial quadrangle about as long as wide (about $9: 8.5$ ); antennae with 3rd segment about one and one-half times as long as broad, a little longer than 4th which is a little shorter than 5th ; ratio of postocellar width to ocelloccipital distance to postocellar distance to ocellocular distance is about $1.5: 3.2: 3.8: 7$; vertex shagreened, well convex and much exceeding line running summits of eyes seen in front; cheeks much broader than eyes seen in profile, its outline distinctly convergent behind seen from above, densely tessellate or nearly shagreened behind. Mesoscutum tessellate, more or less strongly punctate with punctures especially roughened anteriorly, slightly weaker than those on clypeus; scutellum convex, much more weakly punctured than in mesoscutum; mesopleuron nearly dull, strongly roughened; enclosure well indicated, rather finely granulate, wrinkled basally ; mesopleuron coarsely sculptured. Wings as in female. Legs slender, as usual Metasoma smooth and shiny ; 1st and following terga sparsely, weakly to very weakly punctate, occasionally punctures nearly obsolescent; posterior depressions of terga broad (but not so broad as in female), not sharply indicated. Genitalia and subgenital sterna as illustrated.

Distribution: Japan (Hokkaido, Honshu and Kyushu).

Specimens examined: Since the description of this species in 1957, I was able to collect a short series of female and male specimens from Aburaya, Fukuoka, Kyushu, and, also, was able to examine a female specimen from Honshu (Shirahone, Nagano Pref., 19. vii. 1955, S. Kimoto leg.). Furthermore, I had collected a female specimen in Hokkaido (Kawakami, near Honbetsu, Prov. Tokachi, 17-27. vii. 1953). Unfortunately it was overlooked by me in my previous paper. 


\title{
(30) Andrena (Gymnandrena) okabei sapporensis Hirashima
}

\author{
Andrena (Gymnandrena) okabei sapporensis Hirashima, 1957, Mushi, 30 (10): 65.
}

This species occurs in Manchuria and Japan. The present subspecies is known only from the type which is taken in Hokkaido. This species is recognized in having the fulvous pubescence on the thorax and is easily separated from Andrena parathoracica Hirashima in having the white hair bands on the metasomal terga. This species is close to Andrenakoreana Hirashima, which is known from Korea, but is distinguished from the latter by the smaller size, the notched process of labrum, the coarser punctures on the clypeus, the weaker punctures on the mesoscutum, etc.

The type of this subspecies was collected in September, and that of the nominate form in August.

Female : Length about $12 \mathrm{~mm}$.

Colour: Black; about or more than apical halves of mandibles reddened ; malar space piceous; flagellum beneath pale reddish brown ; wings very slightly brownish subhyaline with distal margins slightly darkened; vein and stigma reddish brown; legs nearly piceous with tarsi deep reddish brown; in nominate form, legs much more reddened ; tibial spurs ferruginous ; metasoma with posterior margins of terga narrowly brownish.

Pubescence: Hairs on head short, not specially dense, pale or slightly more yellowish on face including clypeus, occiput and cheeks, brownish on f rons, vertex and cheeks above; facial fovea bright brown above, paler below in some light; hairs on thorax fulvous above, becoming whitish beneath; hairs on mesoscutum and scutellum rather short, sparse medially; hairs on dorsal face of propodeum rather short and scanty; dorsal fringe of propodeal corbicula long, dense, pale fulvous; interior of corbicula with coarse simple hairs ; hairs on trochanters and femora of all legs whitish, those on tibiae and tarsi primarily brownish ; trochanteral floccus imperfect, rather scanty ; femoral floccus dense, not at all silver white, slightly yellowish; tibial scopa compact, composed of moderately long, well arranged, more or less coarse, simple hairs; tibial scopa silvery in front, brownish behind; metasoma scanty of hairs with discs of 1 st and 2nd terga bare ; cilia on 3rd and 4th terga brownish; caudal fimbria nearly fuscous; posterior margin of 2nd tergum with lateral, that of $3 \mathrm{rd}$ with more broad, that of 4th with an entire band of snow white hairs; in nom.inate form, band of 3rd broadly interrupted and that of 4 th obscured medially.

Structure: Head moderate in size; mandibles robust, moderately long ; malar space very narrow ; process of labrum rather small, specially shiny, deeply notched apically: the latter character rather unique for species of Gymnandrena ; clypeus more or less well convex, tessellate, densely and coarsely rugoso-punctate, without an indication of median, langitudinal, impunctate line; in nominate form, punctures on clypeus more stronger and regular in form; clypeus slightly exceeding line running bases of eyes, its index about $2.2: 1.4$; facial quadrangle slightly longer than broad (about $10: 8.2$ ); facial fovea rather deep, separated from eye by a punctate, raised space ; antennae with 3rd segment about equal to next two segments together; 4th segment broader than long, 5th approximately as long as broad ; ratio of postocellar width to ocelloccipital distance to postocellar distance to ocellocular distance about $1.8: 3.2: 4: 5.7$; cheeks rounded, slightly broader than eyes seen in profile, tessellate-punctate. Mesoscutum nearly roughened 
anteriorly and laterally, narrowly nearly smooth and rather weakly punctate posteriorly, with enamel-like lustre ; scutellum nearly as in mesoscutum ; propodeum nearly dull, strongly roughened; enclosure well indicated, rugose, or more' roughened basally; mesopleuron tessellate with roughened punctures. Wings with 2 nd submarginal cell receiving 1st recurrent vein at middle of cell; basal vein interstitial with nervulus. Legs with mid basitarsi slender, subequal to hind basitarsi in widtd; tibial spurs normal. Metasomal terga weakly shiny, microscopically tessellate, not at all polished, densely punctate; punctures on 4th tergum nearly obsolescent; punctures on 1 st tergum finer and more close than in Andrena parathoracica Hirashima; posterior depressions of terga not so broad as in parathoracica, weakly indicated, with very fine and close punctures.

Male: Unknown.

Distribution: Japan (Hokkaido). The nominate form is known from Manchuria.

Flower record: Not available.

\section{(31) Andrena (Gymnandrena) edashigei Hirashima}

Andrena (Gymnandrena)edashigei Hirashima, 1950, Mushi, 33 (8):58, male and female.

This is a tiny species of the subgenus Gymmandrena in our region. The recognition of it is easy owing to the very strongly convex clypeus in both sexes, the presence of the fulvous and blakened hairs on the thorax, the presence of the hair bands on the metasomal terga in the female, and the shiny and sparsely punctate metasoma. This species is best refered to Andrenakoreana Hirashima, from Korea, but is readily distinguished from that species in having the characters mentioned above.

According to the collecting data, this species appears from the late March to April. So far as known, it occurs in Amami-Oshima alone.

Female: Length about or slightly over $10 \mathrm{~mm}$.

Colour: Black; mandibles reddened apically; basal tubercles of mandibles also reddened ; flagellum beneath reddish brown; wings smoky with distal margins slightly darkened; veins and stigma brown; tegulae bright reddish brown, darkened anteriorly; legs piceous or deep reddish brown; tibial spurs yellowish brown; metasoma black or partly piceous, with posterior margin of metasomal terga broadly yellowish transparent.

Pubescence: Hairs on head moderately long and dense, primarily fulvous except for brown hairs on sides of face, frons, vertex and cheeks above near eyes; facial fovea bright in some light, brown above, slightly yellowish beneath ; hairs on mesoscutum, scutellum and metanotum more or less long, dense, bright fulvous, mixed with dense fuscous hairs on mesoscutum and scutellum; hairs on propodeum and mesopleuron pale fulvous; hairs on dorsal face of propodeum somewhat long and dense; dorsal fringe of propodeal corbicula well developed, long, dense and curled ; interior of corbicula with coarse, simple, yellowish hairs; hairs on trochanters and femora pale to distinctly yellowish, those on outerfaces of tibiae and tarsi primarily brownish to fuscous; trochanteral floccus imperfect, rather scanty; femoral floccus long, dense; tibial scopa compact, composed of rather long, coarse, simple hairs; tibial scopa fuscous, narrowly yellowish in front; metasoma scanty of hairs; cilia on 2 nd and following terga fuscous; caudal 
fimbria deep fuscous ; posterior margin of 2 nd metasomal tergum with lateral, that of 3 rd complete or narrowly interrupted, and that of 4 th complete bands of dense, appressed, yellowish hairs ; sparse, loose, yellowish hairs present on 1 st tergum laterally.

Structure: Head moderate in size, rather transverse in front view; mandibles long, moderately robust; malar space narrow but well noticeable, about one-fifth time as long as base of mandible; process of labrum transverse, emarginate apically ; clypeus shiny, considerably strongly convex, rather coarsely, more or less strongly punctate, without a distinct, longitudinal, impunctate space ; clypeus only slightly exceeding line running bases of eyes, its index about $2.2: 1.2$; facial quadrangle only slightly longer than broad (about $8.5: 7.6$ ); lower paraocular area much weakly punctate than in clypeus; facial fovea broad with inner margin and upper end not sharply indicated, separated from eyes margin by a wide, punctate space ; antennae with 3rd segment about as long as 4 th plus 5 th; vertex shagreened; ratio of postocellar width to ocelloccipital distance to postocellar distance to ocellocular distance about $1.7: 2.6: 3: 5.4$; cheeks about as broad as eyes in lateral view, receding, slightly rounded posteriorly, weakly tessellate-punctate. Mesoscutum densely tessellate with roughened punctures anteriorly and -laterally, narrowly nearly smooth and weakly punctate posteriorly; scutellum shiny and weakly punctate anteriorly, roughened posteriorly ; propodeum dull, coarsely sculptured with an indication of roughened punctures; *enclosure more or less well indicated, longitudinally rugulose basally, shiny and finely tessellate apically ; mesopleuron slightly more coarsely sculptured than in dorsal face of propodeum. Wings with 2nd submarginal cell receiving 1 st recurrent vein about middle of cell; basal vein much distad of nervulus. Legs with mid basitarsi hardly expanded medially, a little narrower than hind basitarsi; tibial spurs normal. Metasoma smooth and highly shiny; 1 st tergum with sparse, microscopical fine punctures; 2nd and following terga densely and finely punctate with punctures becoming sparser and finer on posterior depressions which are broad but not well indicated.

Male: Length $8-9 \mathrm{~mm}$.

Colour: Black ; mandibles reddened apically ; flagellum beneath reddish brown ; wings subhyaline with distal margins slightly darkened; veins and stigma brownish, the latter reddish brown medially; legs piceous or nearly black with small segments of tarsi brownish; metasoma black or piceous with posterior margins of terga broadly yellowish transparent.

Pubescence: Hairs on face including clypeus dense, rather long, those on the rest of head not specially dense, more or less uniformly dull pale fulvous except for brownish hairs on sides of face, frons, vertex, and cheeks above near eyes; hairs on thorax long and rather abundant, pale to bright fulvous above, paler below, intermixed with spurse to more or less dense fuscous hairs on mesoscutum and scutellum; hairs on legs primarily yellowish; hairs on metasomal terga short, scanty, those on 1st tergum yellowish, those on following terga brown to fuscous; posterior margins of $2 \mathrm{nd}$ and $3 \mathrm{rd}$ terga or occasionally further on 4 th tergum with sparse, yellowish, fringe-like hairs laterally.

Structure: Head broader than thorax seen from above; mandibles moderately long, rather robust; malar space about one-fourth time as long as base of mandible; process of labrum transverse, convex, shiny emarginate apically ; clypeus short, considerably strongly convex medially, nearly shagreened with an indica- 
tion of weak punctures except for top of convexity where shiny and sparsely punctate; clypeus only slightly exceeding line running bases of eyes, its index about 2 :0.6; facial quadrangle about as long as broad (about $7.3: 7$ ); antennae moderately elongate, with $3 \mathrm{rd}$ segment slightly longer than broad, approximately as long as 4th; vertex well arched in front view, shagreened; ratio of postocellar width to ocelloccipital distance to postocellar distance to ocellocular distance about $1.5: 2.7: 3.4: 5.4$; cheeks about as broad as eyes seen in profile, receding, weakly tessellate-punctate. Mesoscutum densely tessellate anteriorly, weakly so posteriorly, with more or less coarse punctures; scutellum shiny anteriorly, weakly punctate ; propodeum roughened, dull ; enclosure more or less well indicated, rugulose basally, finely tessellate apically or occasionally broadly rugulose ; mesopleuron more coarsely sculptured than in propodeum. Wings as in female. Legs slender, as usual. Metasoma smooth and highly shiny; 1st tergum constricted medio-laterally, scattered with microscopical fine punctures ; 2nd and following terga more densely and slightly more distinctly punctate with punctures becoming weaker on posterior depressions which are more or less broad but not well indicated. Genitalia and subgenital sterna as illustrated.

Distribution: Japan (Amami-Oshima).

Spccimensexamined: 2 females, Amami-Oshima, 23. iii. 1958 (M. Takahashi);8 males, Amami-Oshima, 2. iv. 1958 (M. Takahashi).

Flower record: Not available.

\section{(32) Andrena (? Gymnandrena) snsakii Cockerell}

Andrena sasakii Cockerell, 1913, Ann. Mag. nat. Hist., (8) 11. : 189, male ;Yasumatsu, 1914, Peking nat. Hist. Bull., 15: 28J; Uéda, 195-2, Trans. Shikoku ent., Soc., $4: 50$.

Andrena alopex Cockerell, 1917, Entomologist, 50 : 86, female ; Yasumatsu, 1941, Peking nat. Hist. Bull., 15: 273. New synonym.

The present species is provisionally placed in Gymnandrena here since the general habitus is close to most species of the subgenus. One of significant characters which renders me to make uncertain is the metasomal terga on which more or less roughened punctures present. Further more the male genitalia is slightly apart in strcture from those of typical representative of Gymnandrena. It seems probable that this species is not at all unrelated to Zonandrena of the Palaearctic Region.

This species is one of the commonest Andrena that fly in the spring in Japan. It occurs in abundance throughout Kyushu and western Honshu and principally associates with flowers of Brassica. Among the andrenid bees that visit Brassica this species is easily recognizable by its large and robust form, and the presence of ths fulvous hairs on the head and thorax.

Synonymy: Andrena snsakii Cockerell was originally described from the male. The female of sasnkii quite agrees with the description of Andrenaalopex Cockerell. I have long considered that alopex is a synonym of sasakii. Prof. Yasumatsu was kind enough to examine the type specimens of them in the United States and supported my opinion.

According to the literature, it seems probable to me that sasakii is a synonym of Andrenx consimilis Alfken, 1900. There is a need of the careful examination of the type specimen for the accurate identification of the latter. 
Female: Length 12-13 mm., occasionally more larger.

Colour: Mandibles reddened apically; bases of mandibles sometimes obscurely reddened ; flagellum beneath reddish brown; wings brownish subhyaline, with distal margins slightly more darkened; veins and stigma brown, the latter reddish medially ; tegulae brownish transparent posteriorly, deeper brown anteriorly ; legs piceous, tibiae and tarsi, especially hind ones, slightly to more or less distinctly reddened or deep reddish brown ; tibial spurs yellowish brown; rarely metasomal terga obscurely steel blue; posterior margins of metasomal terga reddish brown to narrowly yellowish transparent.

Pubescence : Hairs on head and thorax rather short to more or less long, dense, those on metasoma rather short to short, dense, fine, therefore not conspicuous; hairs on clypeus more or less dense, rather fine, yellowish; hairs on antennal regions fulvous, those on occiput and cheeks slightly paler; hairs on frons and vertex brown or nearly fuscous; facial fovea brownish, bright in some light; hairs on thorax pale fulvous to fulvous above, slightly paler below, without admixture of darker hairs; dorsal fringe of propodeal corbicula long, dense, not well arranged ; more than upper one-half of interior of propodeal corbicula with coarse hairs which slightly branched and whitish; trochanteral floccus imperfect, more or less dense, yellowish; femoral floccus bright, yellowish; tibial scopa well developed, composed of rather coarse, well arranged, principally simple hairs ; tibial scopa bright, silvery or distinctly yellowish in front, obscurely to more or less distinctly brownish above; hairs on 1st tergum and median bases of 2nd more or less long, yellowish, those on the rest of 2nd and following terga short, suberect to downy, primarily brownish; posterior margin of 2 nd tergum with lateral, that of 3rd with more broad or occasionally nearly complete, that of 4th with complete fringes of dense, short, appressed or nearly so, whitish or white hairs; caudal fimbria bright fuscous.

Structure: Head of moderate size, somewhat quadrate in front view; mandibles rather long, robust; malar space about one-fifth time as long as base of mandible, slightly widened posteriorly; process of labrum large, with apical margin almost rounded, entire ; clypeus well convex, narrowly tessellate basally, broadly nearly smooth, densely punctate with punctures somewhat coarse and strong medially, without median, impunctate, raised line ; clypeus somewhat well exceeding line running bases of eyes, its index about $2.3: 1.8$; facial quadrangle slightly longer than broad (10.3 : 9.2); facial fovea separated from eye by a punctate space, broad but not sharply indicated; antennae moderately long, with 3rd segment about equal to next two segments together; ratio of postocellar width to ocelloccipital distance to post ocellar distance to ocellocular distance is $2: 3.5: 4: 6.5$; cheeks slightly broader than eyes seen in profile, rather convex, shagreened. Mesoscutum tessellate, with about or more than anterior half shagreened or nearly roughened; punctures on mesoscutum sparse, weak, considerably weaker than those on clypeus; scutellum slightly convex, somewhat densely punctate with punctures a little stronger than those on mesoscutum; propodeum roughened, dull ; enclosure ill defined, strongly tessellate or nearly shagreened, weakly wrinkled basally; mesopleuron broadly nearly roughened, narrowly nearly shagreened posteriorly. Wings with 2nd submarginal cell receiving 1st recurrent vein about or slightly beyond middle of cell; basal vein almost interstitial with or slightly distad of nervulus. Legs with mid basitarsi indistinctly dilated medially, slightly narrower than hind basitarsi; posterior spurs of hind tibiae neither widened nor distinctly 
curved basally. Metasomal terga weakly shiny; 1st tergum densely tessellate, with weak, rather sparse, more or less roughened punctures; 2nd and following terga weakly tessellate, somewhat densely punctate with punctures weak and a little roughened; posterior depressions of terga broad, not well indicated.

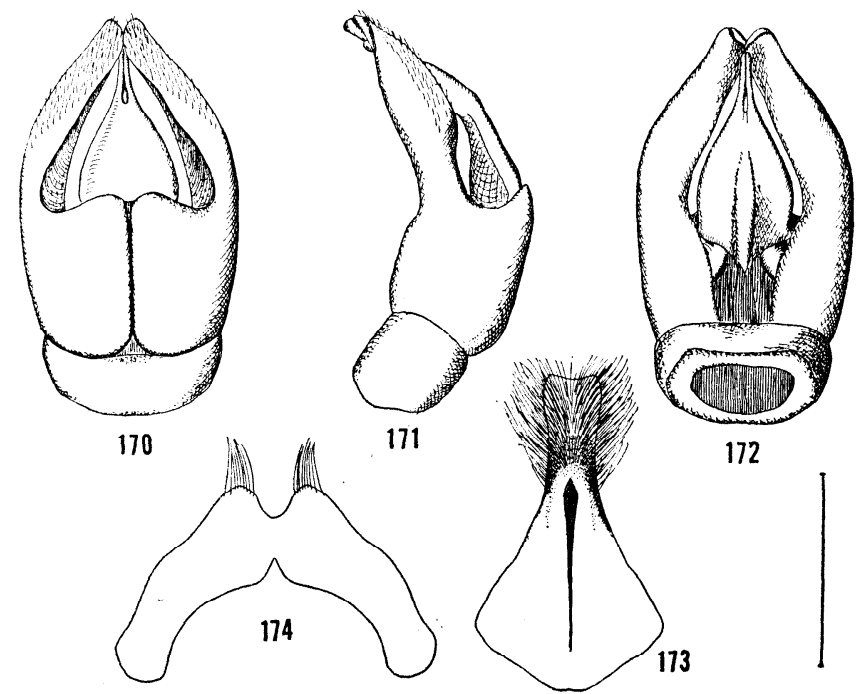

Figs. 170-173. Genitalia and associated structures of male Andrena (? Gymnandrena) sasakii Cockerell.

Fig. 170: dorsal view of genitalia, 171: lateral view of the same,

172: ventral view of the same, 173: 8th sternum, 174: 7th sternum.

Male: Length 10-11 mm., occasionally more larger.

Colour: Black ; mandibles broadly reddened apically ; bases of mandibles obscurely reddened ; flagellum beneath reddish brown ; wings slightly brownish subhyaline, with distal margins indistinctly more darkened; veins and stigma brownish to reddish brown; tegulae brownish subhyaline posteriorly, deeper brown anteriorly; legs black or piceous, tarsi brownish ; posterior margins of metasomal terga reddish brown to narrowly yellowish transparent.

Pubescence: Hairs on head and thorax rather long to long, abundant but not obscure integument, those on metasoma rather short to short, more or less dense, fine, therefore not conspicuous; hairs on full body, including legs, almost uniform in colour, pale fulvous (bright on metasoma), not mixed with brownish hairs on any portion ; hairs on clypeus erect basally, becoming downy apically ; hairs on posterior margins of 2 nd to 4 th terga denser than those on elsewhere, forming indistinct fringes.

Structure: Head rather large, broader than thorax seen from above, somewhat quadrate in front view; mandibles moderately long, robust; malar space about one-fourth time as long as base of mandible, slightly widened posteriorly; process of labrum large, transverse, well convex, nearly smooth and shiny; clypeus well convex, tessellate or sometimes narrowly nearly smooth medially, densely punctate with punctures not strong, rather small; clypeus slightly exceeding line running 
bases of eyes, its index about $2: 1.3$; facial quadrangle slightly longer than broad (about $8.8: 7.6$ ); antennae long, with 3rd segment about one and one-half times as long as broad, indistinctly shorter than 4th which is about as long as 5th; 5th and following segments slightly convex anteriorly; ratio of postocellar width to ocelloccipital distance to postocellar distance to ocellocular distance is 1.5 : $3: 3.7$ : 5.9; cheeks slightly broader than eyes seen in profile, its outline distinctly convergent behind seen from above, shagreened. Mesoscutum densely tessellate or shagreened, nearly dull, weakly punctate with punctures more or less roughened; scutellum well convex, shagreened with indication of more or less roughened punctures ; propodeum roughened, dull ; enclosure ill defined, wrinkled basally, shagreened apically; mesopleuron shagreened or nearly roughened, about as coarse as or a little less coarsely sculptured than propodeum. Wings nearly as in female. Legs as usual. Metasonal terga densely tessellate with weak, not specially dense punctures, those of 1 st tergum and base of 2 nd more or less roughened; posterior depressions of terga somewhat well indicated. Genitalia and subgenital sterna as illustrated.

Distribution: Japan (Honshu, Shikoku and Kyushu).

Specimens cxamined: A long series of male and female specimens primarily from Kyushu has been examined.

Flozerrecords: This species primarily associates with the flowers of Brassica spp. 